\title{
The Rio de la Plata Cratonic Region of Southwestern Gondwanaland
}

\section{by Luis Dalla Salda, Jorge Bossi and Carlos Cingolani}

\begin{abstract}
Middle Precambrian to early Paleozoic orogenesis can be recognized in formerly adjacent parts of southwestern Africa and eastern South America, especially in southern Brazil, Uruguay and eastern Argentina. The Transamazonian and Brazilian cycles are represented by a variety of rocks and tectonic settings, some of which were reviewed in the September issue of Episodes by Ramos and Rapela and Kay. This article is one of the first to relate the Precambrian units of Uruguay to the Tandilia ranges of Argentina, where both cycles are well displayed. (Ed.)

Introduction
\end{abstract}

The Precambrian and some of the lower Paleozoic units of southwestern Gondwanaland comprise four main lithological groups. In South America, the first occurs in the $\mathrm{R}$ io de la Plata craton, which embraces southern Brazil and Uruguay to the north and the Tandilia region of Argentina to the south (Almeida et al., 1977) and in southern Africa the western extension of the Kalahari craton (Fig. 1). These terranes exhibit similar age ranges from middle to late Precambrian (2.2-1.7 Ga).

The second group comprises the late Precambrian Damara, Gariep and Malmesbury mobile belts of southern Africa and their equivalents in South America (see Fig. 1): Dom Feliciano in southern Brazil, Ciclo Orogenico of Uruguay $(900-500 \mathrm{Ma})$, and the Punta Mogotes and Sauce Chico Groups of the Tandilia and Ventana hills in Argentina. These South American equivalents are the main components of the Brazilian orogenic belt that comprises with its African counterparts a late Precambrian belt that evolved in a plate tectonic setting between the South America and Africa platforms (Porada, 1979, and Fragoso et al., 1982).

$\overrightarrow{\text { Figure 1: Regional }}$ geology of southwestern Gond wanaland, indicating the area discussed in this article.

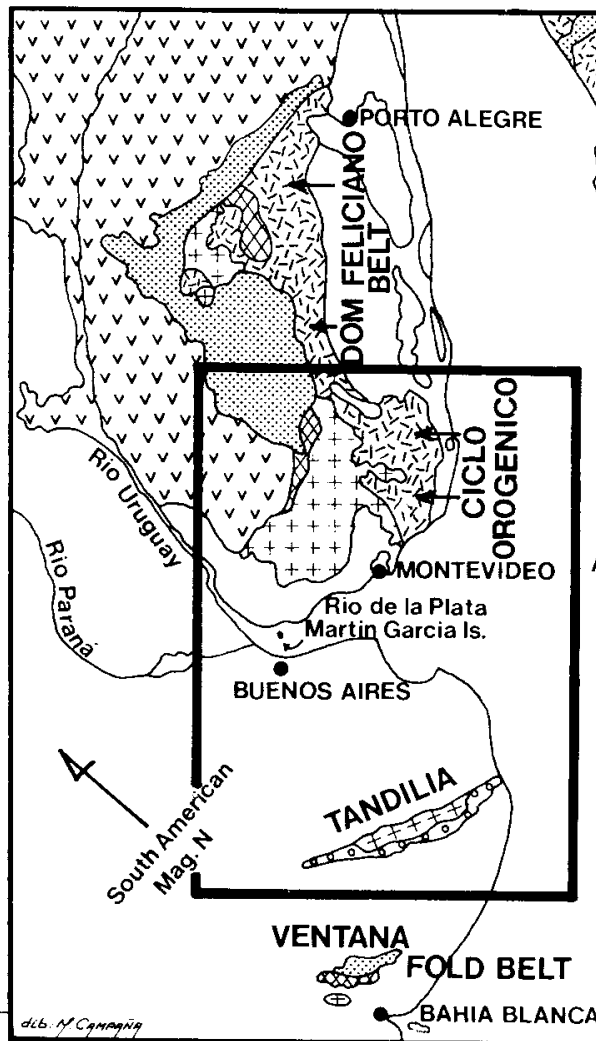

The third group is represented by the Pampeanas ranges of central Argentina (see Ramos, 1988). This group originated during an important calc-alkaline Paleozoic granitic cycle that overprinted younger ages on the Precambrian metamorphic complex into which the granites were emplaced.

The fourth late Precambrian to early Paleozoic group of units is mainly sedimentary and began its evolution with the lower La Tinta Group in Argentina, the Nama Group in Africa and possibly the Piedras de Afilar Formation in Uruguay. In Argentina and Africa these units continued their evolution during part of the early Paleozoic when they were affected by the final phases of the Brazilian-Pan African orogenesis. In Brazil and Uruguay the sedimentation linked with this tectonic eycle is mainly continental and molassic.

The Rio de la Plata Cratonic Cycle

The Uruguayan "shield" was stabilized in early Paleozoic times, for the oldest non-orogenic sediments recognized are Early Devonian. This pre-Devonian craton was affected by two orogenic cycles: a middle Precambrian one about $2 \mathrm{Ga}$ ago, and a younger one active from late Precambrian (900 $\mathrm{Ma}$ ) to the early Paleozoic (500 Ma).

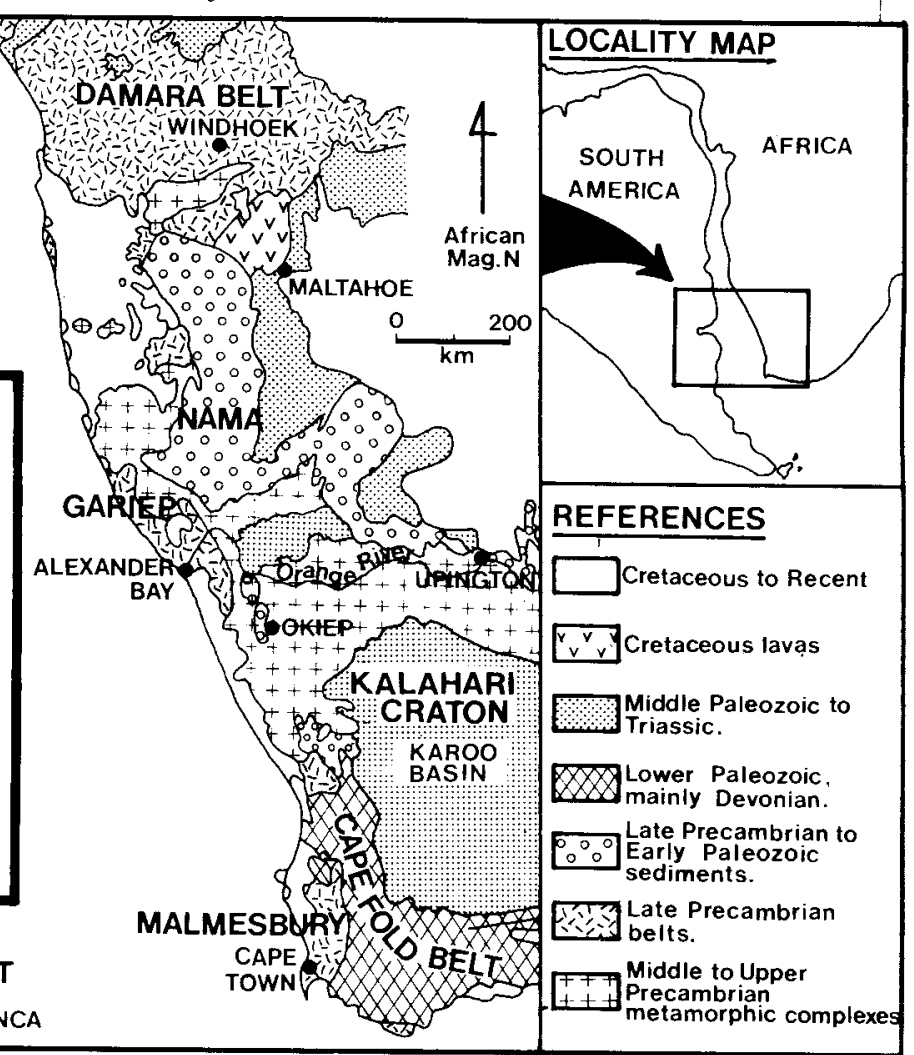


The Rio de la Plata craton with rocks older than $1.7 \mathrm{Ga}$ crops out over much of southern Uruguay (Fig. 2). An east-west fault that runs from Fray Bentos to Valentines (Bossi, 1983) divides the craton into two domains with different lithological and structural features. The northern domain is characterized by migmatite complexes cored by granites that are medium grained and non-porphyroblastic, in which microcline has intergrown with oligoclase as a string perthite. The metamorphic rocks are mainly biotite-oligoclase gneisses associated with clinopyroxene gneisses, quartzites with magnetite and augite, and biotite schists. Near the Fray Bentos-Valentines fault, there are two superimposed megascopic fold phases, the first trending northwest, the other ENE (Fig. 3). To the north, around Minas de Corrales (Fig. 2), only the northwest set of folds can be seen. An age of $2272 \pm 33 \mathrm{Ya}$ was determined on rocks from this region by Soliani (1986).

South of the Fray Bentos-Valentines fault are widespread granite-migmatite complexes in three ENE-WSW strips bounder by faults. The granitic complexes are porphyroblastic with microcline megacrysts in a biotite granodiorite "matrix." The migmatites developed from gneisses and amphibolites and exhibit a regional schistosity also oriented ENE-WSW. The rocks of the metamorphic strips are mainly meta-pelites, arenites and basites. Only two thin lenses of marble have been recognized in the whole area. Three units have been described: the Arroyo Grande chlorite schists and meta-arkoses (Ferrando and Fernandez, 1971), the Paso Severino meta-volcanics, meta-pelites and meta-arenites, and the Montevideo gneisses and amphibolites (Bossi, 1966). Within the strips there are several late-orogenic hornblende-biotite granodiorite plutons and post-orogenic subalkaline leucogranites (Fernandez and Preciozzi, 1974).

In the central part of the granite-migmatite area there is a swarm of ENE-WSW tholeiitic micro-gabbro dikes, as yet undated, in a belt $200 \mathrm{~km}$ long and $30 \mathrm{~km}$ wide. Each dike is several kilometres long and from 10 to $25 \mathrm{~m}$ thick (Bossi and Navarro, 1982).

\section{The Brazilian Orogenic Belt}

Eastern Uruguay is the site of the NNE-SSW-trending, late Precambrian, Brazilian orogenic belt (Fig. 2). The metamorphic grade in this belt increases towards the central region where there are extensive granite-migmatite areas. From west to east the following units can be recognized: Lavalleja Group characterized by low-grade metamorphic rocks such as phyllite marble, dolomitic marble and metabasite; the Carape Group with the same lithology but a

Figure 2: The $m$ ajor lithological units within the Brazilian and Transam azonian cycles of Uruguay. After Bossi (1987).

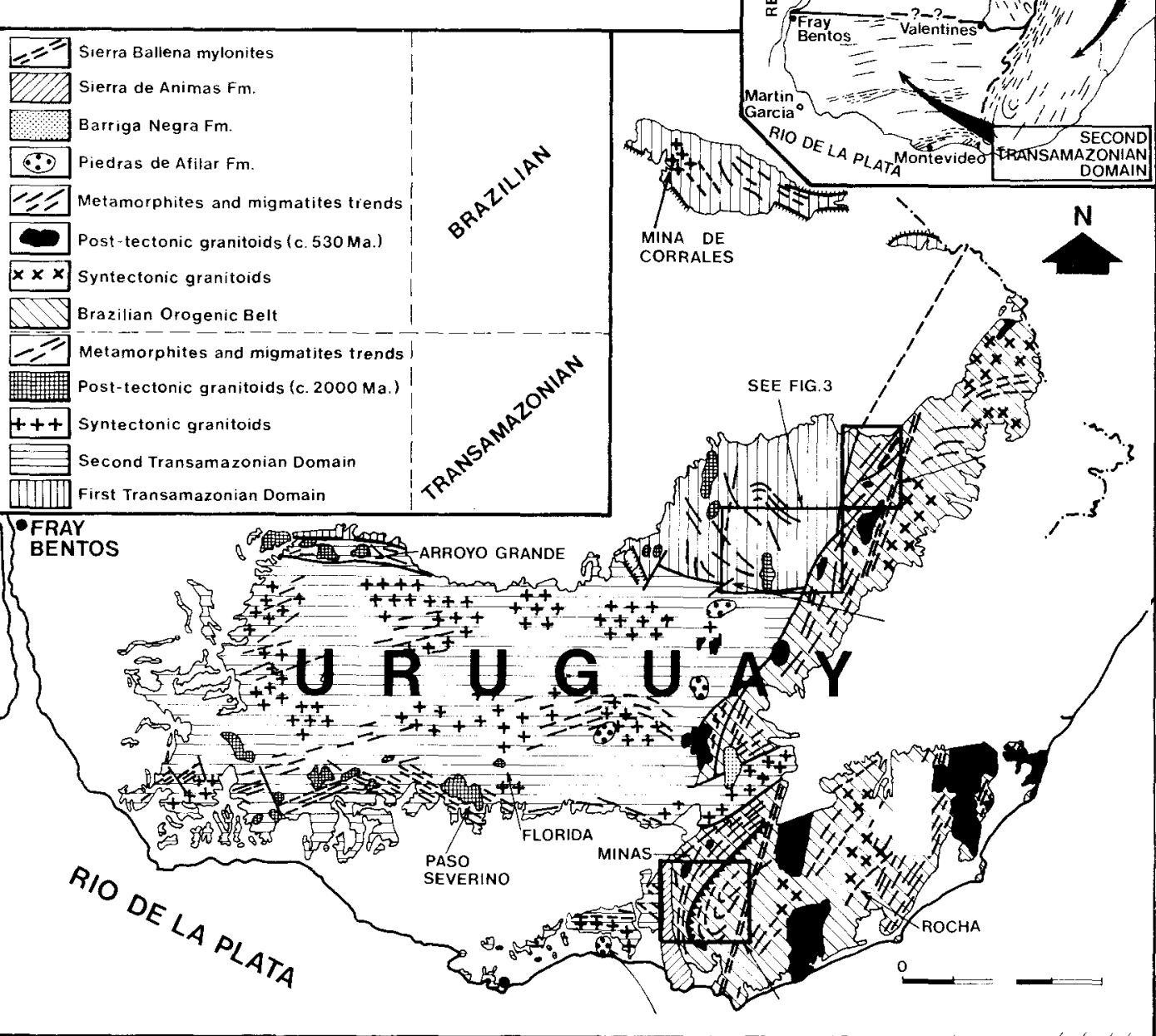




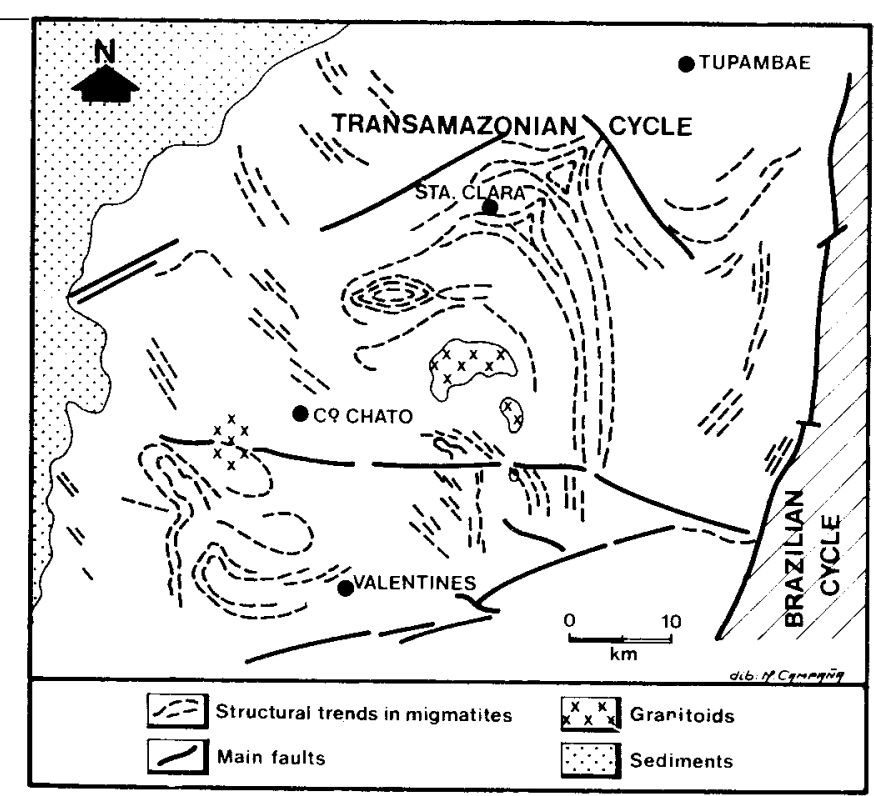

Figure 3: A detail of the Transamazonian and Brazilian cycles in Uruguay. For location see Fig. 2.

medium metamorphic grade; and a wide area of migmatites, syntectonic granites and the Rocha Group with gneisses and mica-schists that grade eastwards to chlorite schists and phyllites (Bossi, 1983, and Preciozzi et al., 1985).

Pre-orogenic activity here appears to have taken place around $900 \mathrm{Ma}$ ago, from K-Ar determinations on two nonmetamorphic basalts. Gneisses and migmatites have $\mathrm{Rb}-\mathrm{Sr}$ ages from 575 to $675 \mathrm{Ma}$, calculated with an assumed initial $\mathrm{Sr}$ ratio of $0.704 \pm .002$ (Umpierre and Halpern, 1971). Syntectonic granites range from 535 to $590 \mathrm{Ma}$ from three isochrons with an initial $\mathrm{Sr}$ ratio of 0.708 . The post-tectonic granites emplaced in low-grade metamorphics yield $\mathrm{Rb}-\mathrm{Sr}$ isochrons from 500 to $550 \mathrm{Ma}$ (Hart, 1966; Umpierre and Halpern, 1971; Bossi et al., 1975).

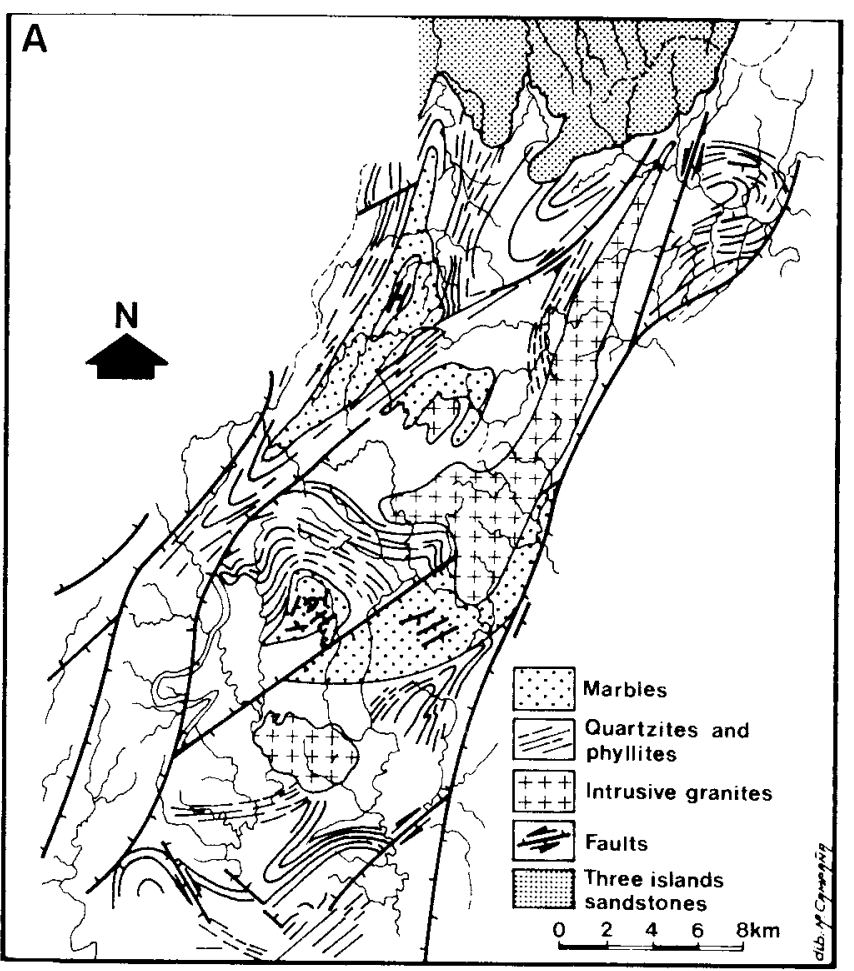

A first deformational phase developed NNE-SSW axial planes and a second one, trending WNW-ESE, produced a dome and basin pattern and strike-slip shearing and thrusting parallel to the first set of axial planes (Fig. 4A \& $4 \mathrm{~B}$ ). The second deformational event is known to be of Late Cambrian (530-500 Ma) age because it deforms the Polanco Granite $(530 \pm 15 \mathrm{Ma})$ and predates the $490 \mathrm{Ma}$-old Sierra de Animas Formation (Fig. 4B).

Late Precambrian to Early Paleozoic Cover

Two different units can be recognized within the sedimentary cover as part of the Uruguavan craton: platform sediments linked to the early evolution of the Brazilian cycle (900-500 Ma) and a molassic deposit that evolved at the end of the cycle.

The first unit, named the Piedras de Afilar Formation was recently described by Coronel and others (1982) as composed of quartzites and pelites with black limestones at the top. This unit crops out above the basement as a $600 \mathrm{~m}$ sequence with moderate southwest dips. Since these unfossiliferous marine sediments exhibit an eastwards paleocurrent direction, Fragoso and colleagues (1987) interpreted them as deposited during the beginning of the Braziljan cycle (late Precambrian).

The second sequence, which is included in the Barriga Negra Formation (Preciozzi et al., 1985), was initiated with a few hundred metres of conglomerate with clasts to $1 \mathrm{~m}$. This unit is followed by $200 \mathrm{~m}$-thick immature conglomeratic and feldspathic sandstones, overlain in turn by $200 \mathrm{~m}$ of cross-bedded sandstone, and at the top by some $100 \mathrm{~m}$ green lutites and siltstones. This sequence is younger than the shearing and thrusting event and contains pebbles of the 530 Ma-old Polanco Granite; a Late Cambrian age is indicated.

\section{The Tandilia Region Basement}

The southernmost middle Precambrian rocks in South America are located in the Tandilia region in southern Buenos Aires Province of Argentina (Fig. 5). This igneousmetamorphic suite was named the Buenos Aires Complex by Marchese and Di Paola (1975). Radiometric data indicates a long geological history, mainly within the Transamazonian cycle (2200 to $1700 \mathrm{Ma})$.

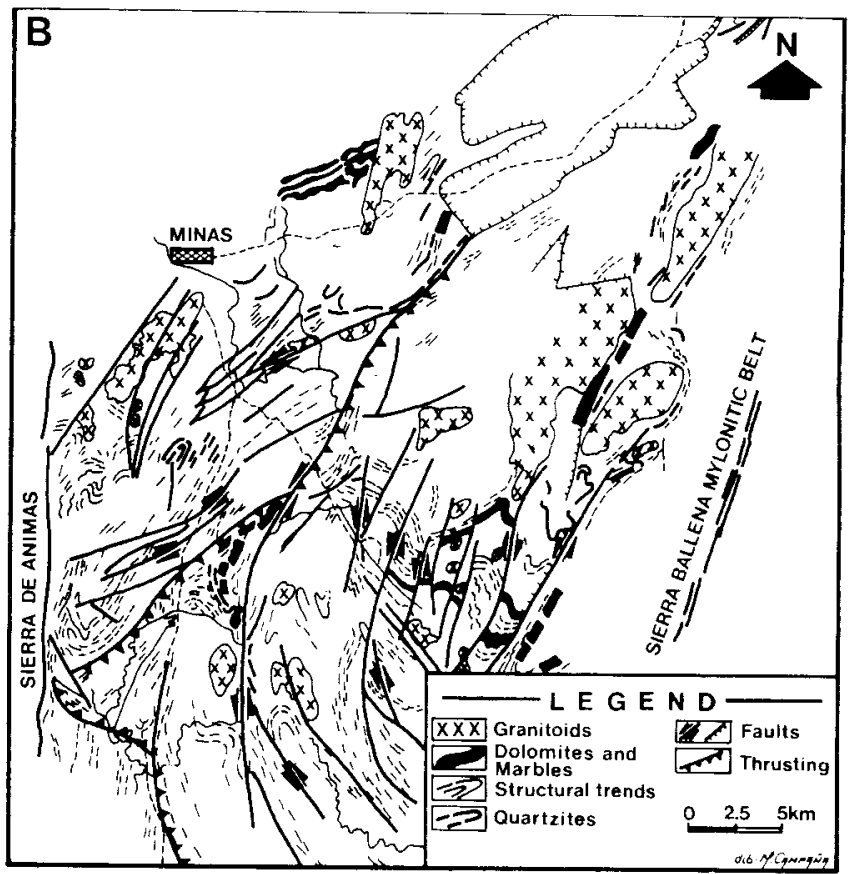

Figure 4: Structural map of the northern and southern Brazilian orogenic belt in Uruguay. Locations shown on Fig. 2 . 
This complex is an array of metamorphic rocks that includes migmatites, granitoids, acidic and basic dikes, as well as eataclastic rocks of mainly granitic composition. The metamorphic rocks are poorly known because of the extensive weathering. They occur as lenses and sheets of gneisses, mica schists, amphibolites and few marbles and acidic metavolcanics. Emplaced into this assemblage are many granitic to tonalitic, syntectonic to late-tectonic plutons with ages from 900 to $2100 \mathrm{Ma}$ (Hart et al., 1965; Halpern and Linares, 1970; Halpern et al., 1970; Teruggi et al., 1973, Dalla Salda, 1981 a and b; Varela et al., 1985 and 1987).

The granites of the Tandilia region are leucogranites south of the east-west mylonitic zone in the Sierra Alta de Vela and Montecristo hills, and granites, granodiorites and tonalites north of this zone in the Federacion, Dos Leones and Movediza hills (Dalla Salda and Franzese, 1987). Analysis of trace elements (Fig. 6A), together with data on major elements, initial $\mathrm{Sr}$ isotope ratios of the Vela leucogranites (Fig. 6B), and the structural and lithological relationships within the basement, all support the assumption that some of the Tandil granites have a collisional anatectic origin.

The cataclastic rocks were described by Gonzalez Bonorino and his colleagues (1956) and Teruggi and others (1958 and 1962) as derived mainly from granitoids. The cataclastic phenomenon developed intensively in several wide shear zones in the Azul and Tandil hills (Dalla Salda, 1981 c). Basic intrusives are represented by amphibolite sheets and by discordant plutons affected by low-grade metamorphism and hydrothermal alteration (Teruggi et al., 1974).

A first deformational episode (F l) characterized by isoclinal recumbent folds trending east-west provides evidence of an initial early Transamazonian tectonothermal event. The main $\mathrm{F} 2$ deformational event is linked to a $1850 \mathrm{Ma}$ granitic episode and resulted in a NE-SW structural alignment that

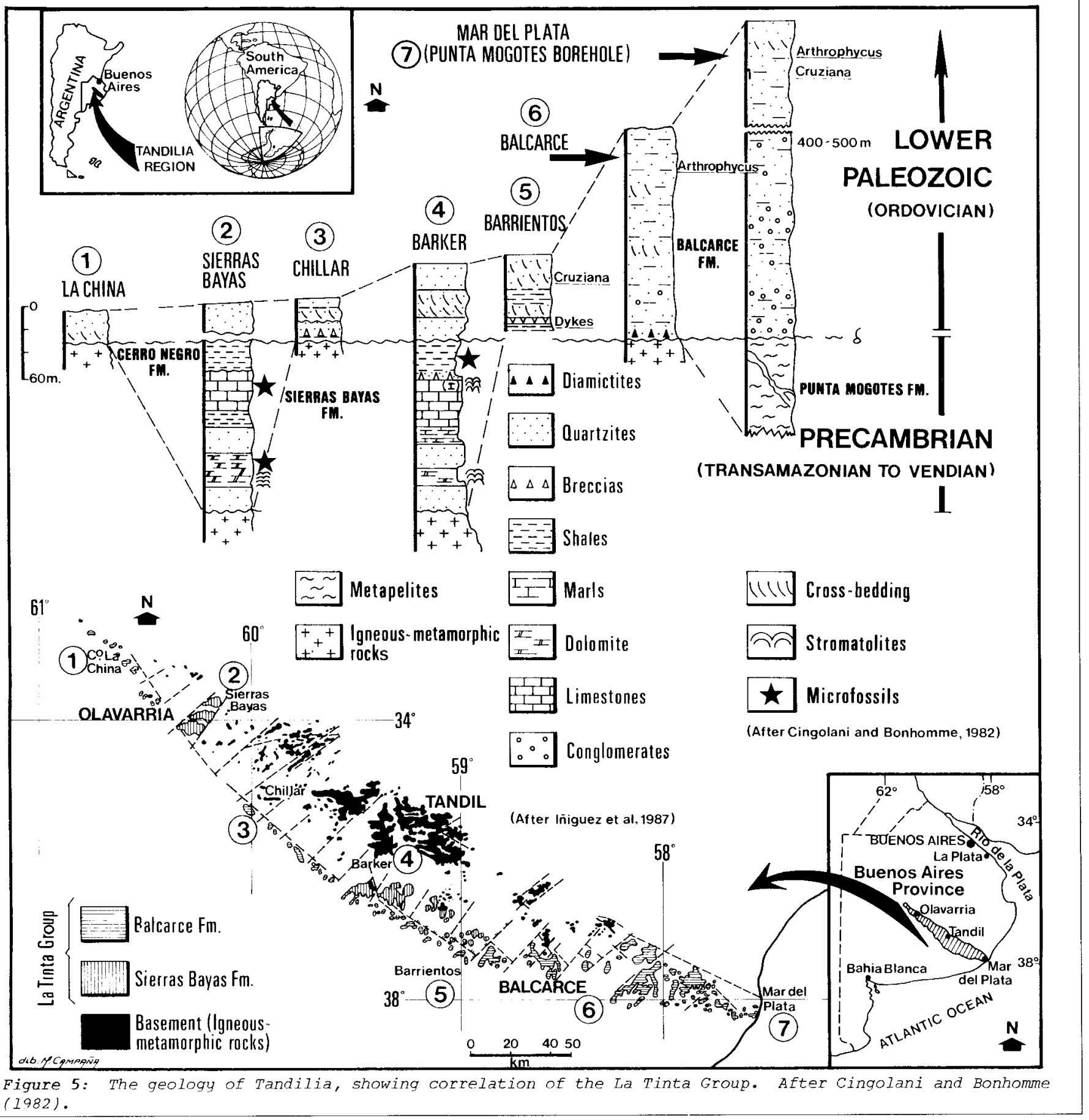



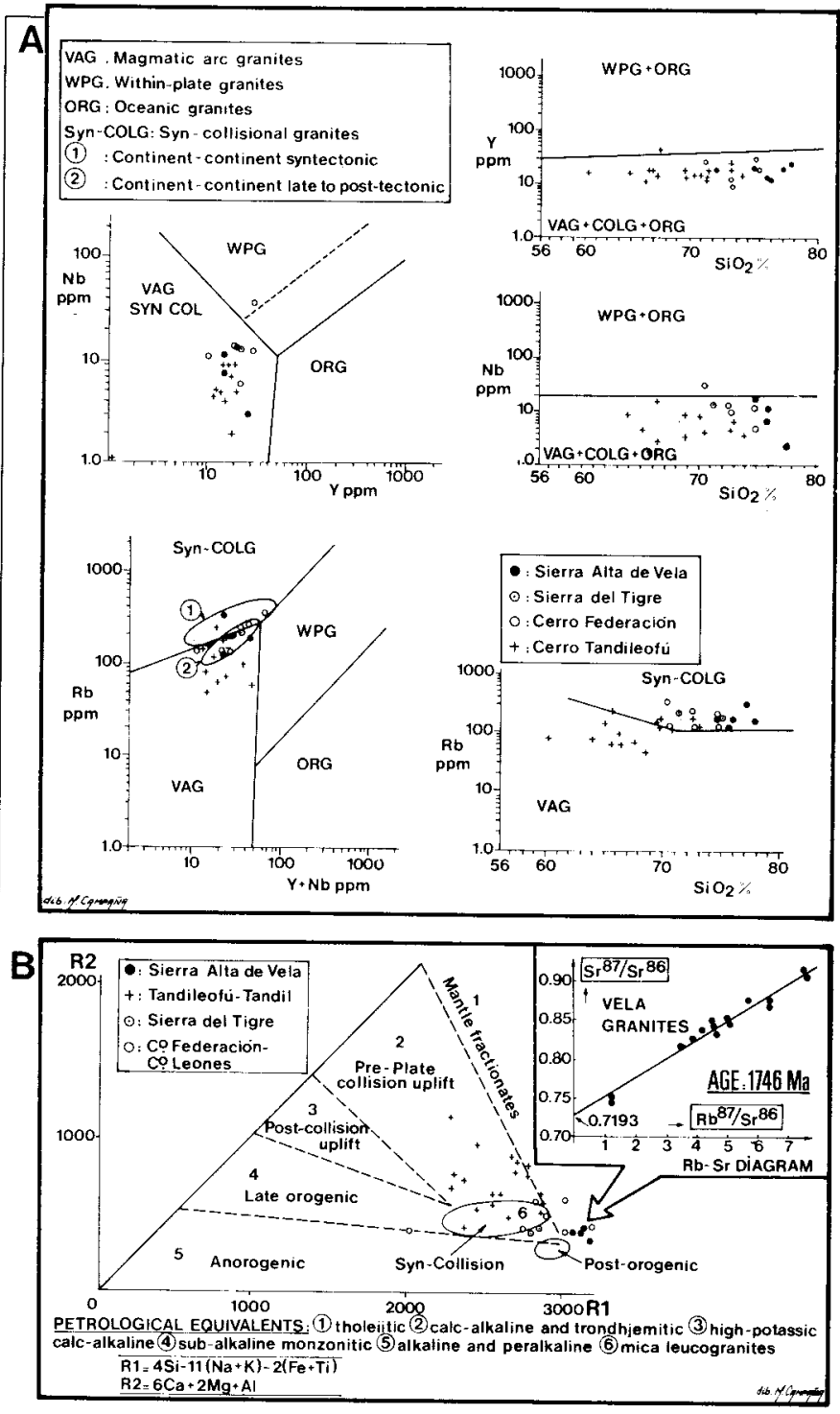

Figure 6: Geochemistry of Tandilia granitoids. For explanation see text. A - Pearce (et al., 1984) diagrams, B - Batchelor and Bowlen (1985) diagram.

deformed $F 1$ trends. A third tectonic event (F3) gave rise to a fold system with various styles of folding, but mainly with high-angle $\mathrm{N} W-\mathrm{SE}$ axial planes that crosscut the older trends (Fig. 7). A late metamorphic event resulted in the formation of retrograde chlorite grade rocks (Teruggi et al., 1973). Part of the ancient structure of this crystalline basement was considered the product of a wrench tectonic model by Dalla Salda (1981 c).

\section{Sedimentary Cover in Tandilia}

In a deep borehole near Mar del Plata at the eastern end of the Tandilia region the bottom $80 \mathrm{~m}$ intersected very lowgrade metapelites $500 \mathrm{~m}$ below the early Paleozoic quartzitic Balcarce Formation (Fig. 5). K-Ar determinations give ages of 576 to $615 \mathrm{Ma}$, interpreted as the age of the last thermo-tectonic episode (Cingolani and Bonhomme, 1981). This Punta-Mogotes Formation can be correlated with some of the meta-pelitic rocks of the 900-500 Ma Brazilian Cycle of Uruguay.

The La Tinta Group (Dalla Salda and Iñiguez, 1978) is the late Precambrian to lower Paleozoic sedimentary cover of the Buenos Aires Complex (Fig. 5). This group comprises the Sierras Bayas, Cerro Negro, and Balcarce formations. These are widely distributed through $400 \mathrm{~km}$ along the southwestern margin of the Tandilia ranges, dipping very slightly to the south.

The Sierras Bayas Formation is composed of around $150 \mathrm{~m}$ of quartzites, dolomites, illitic pelites, black and reddish limestones and marls. The $35 \mathrm{~m}$-thick dolomitic member contains late Precambrian stromatolites, and acritarchs are found in the limestones (Pothe de Baldis et al., 1982). $\mathrm{Rb}-\mathrm{Sr}$ isochron data indicate a diagenetic age of $769 \pm 12 \mathrm{Ma}$ (Bonhom me and Cingolani, 1980) from nine pelites, with an initial Sr ratio of 0.7121 .

The Cerro Negro Formation (Iñiguez and Zalba, 1974) is essentially composed of green and gray shales with some phosphorites and a locally developed basal talus breccia (Dalla Salda et al., 1972) that contains limestone, pelite and marl pebbles in a quartzose matrix. In boreholes it has been found up to $150 \mathrm{~m}$ in thickness. An $\mathrm{Rb}-\mathrm{Sr}$ isochron shows a $723 \pm 19$ Ma age for the shales, with an initial $\mathrm{Sr}$ ratio of 0.7171 (Bonhomme and Cingolani, 1980).

The Balcarce Formation consists mainly of a thick white quartzite sequence with a few intercalated thin gray kaolinitic shales. It unconformably overlies the rest of the La Tinta Group rocks, as well as the crystalline basement. In the Balcarce area it overlies a diamictite that could be

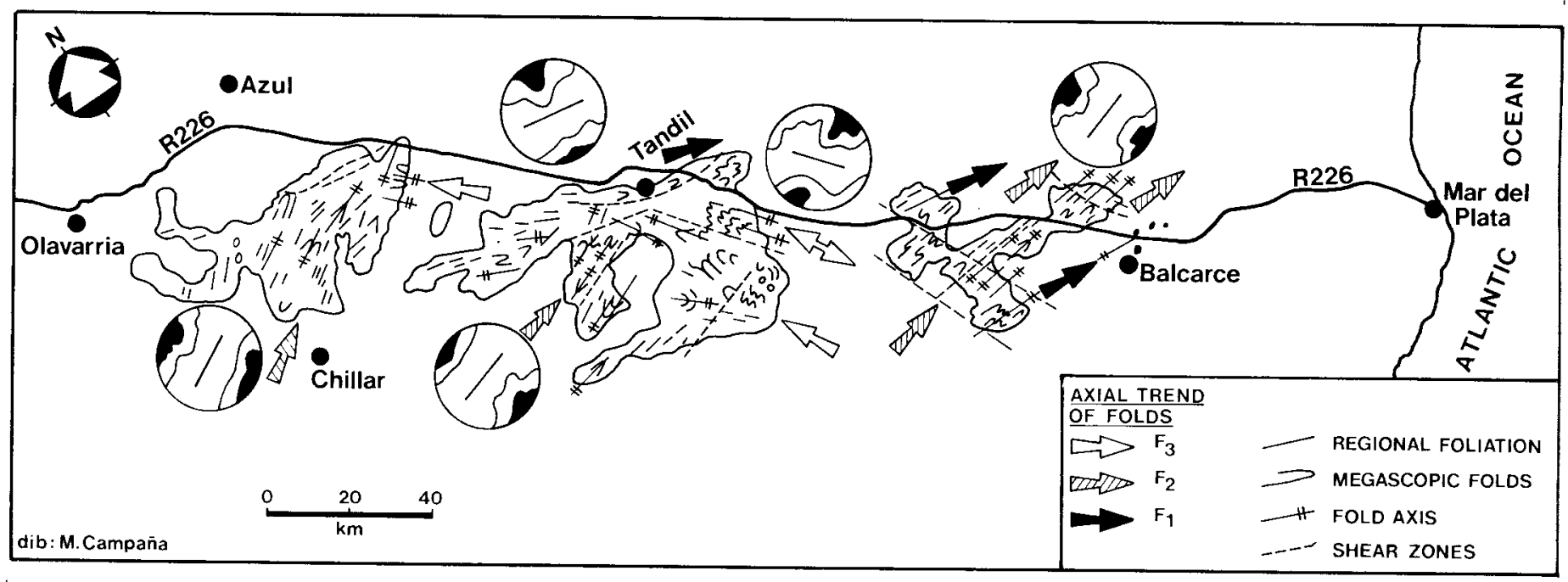

Figure 7: Regional structures of the Tandilia crystalline basement. Stereonets show poles to schistosity and foliation planes. From Teruggi and others (1973, 1974) and Dalla Salda (1975, 1985). 
interpreted as a late Precambrian to early Paleozoic tillite (Spalletti and del Valle, 1984). The Balcarce Formation, which dips gently to the southwest, increases in thickness to $500 \mathrm{~m}$ near Mar del Plata. As this formation is cut by a 450-490 Ma diabase dike (Rapela et al., 1974) and in view of its apparently early Paleozoic ichnofauna (Cruziana and Rusophycus, according to Borrello, 1966) it is interpreted as Early Ordovician in age.

\section{Discussion}

The basement rocks of Uruguay and Tandilia thus belong to two main geotectonic units: the older being the common crystalline basement of Transamazonian age, and the younger the result of the evolution of a late Precambrian to early Paleozoic Brazilian belt. Each geotectonic event is sharply defined and similar on both sides of the Rio de la Plata (Fig. 8).

The early episode may have led to the formation of an ensialic mobile belt as a result of vertical accretion and mobility. Migmatitic and granitic rocks were widespread, and there were few basic and ultrabasic rocks. More than one deformational event produced complicated interference patterns. The orogenic association seems to be similar to that of an Hercynotype model (Zwart, 1967; Pitcher, 1983). It is important to stress that in neither Uruguay nor Tandilia

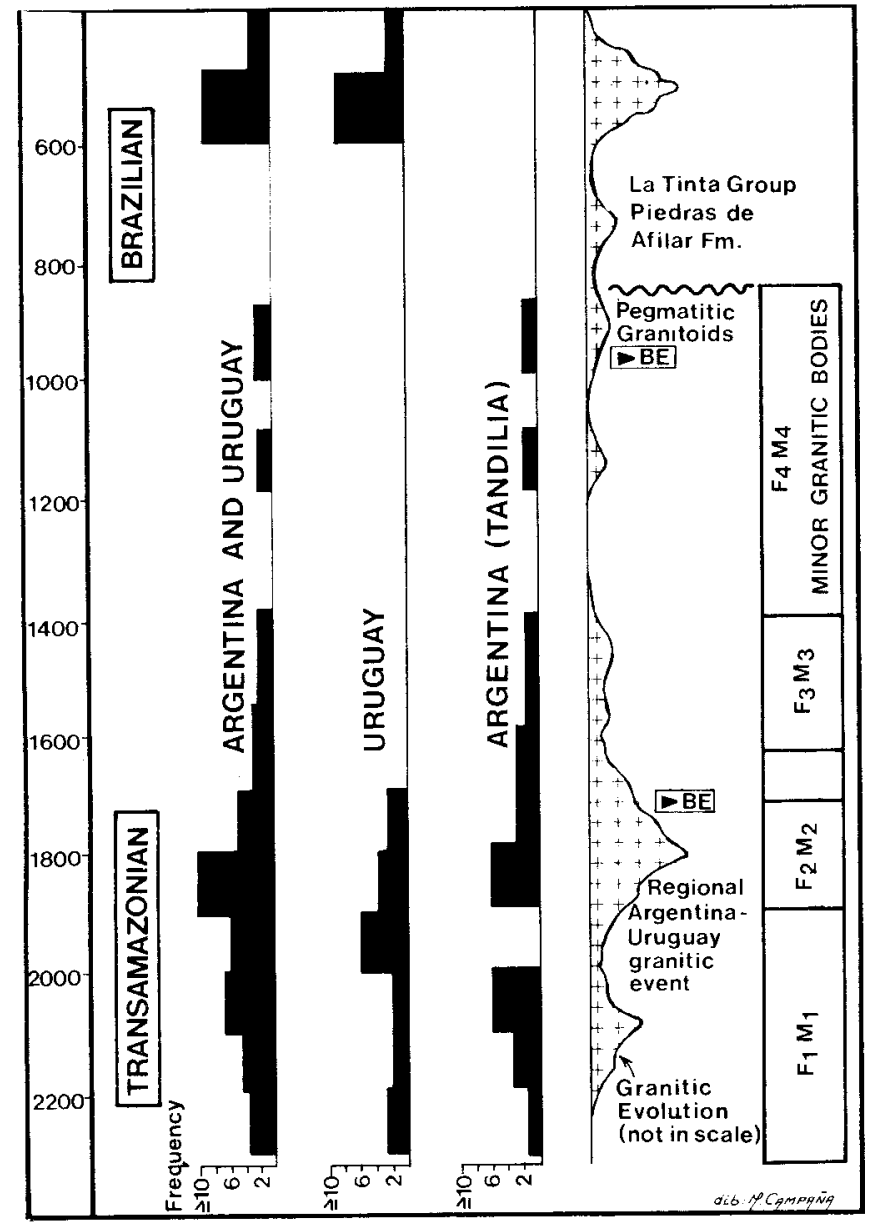

Figure 8: Geochronology of the main igneous, metamorphic $(M)$, deformation $(F)$ and stabilization events in the Rio de la Plata craton. The positions of the late Precambrian to early Paleozoic cover sediments (La Tinta Group and the Piedras de Afilar Formation) are also shown. Histograms show frequency of radiometric dates. BE: basic dikes. In part after Teruggi and others (1973, 1974). have metamorphic minerals been found that indicate high or low-pressure conditions; only index minerals of intermediate pressure are present.

In Tandilia some leucogranites appear to have developed as the result of collisional tectonics, associated with wrench faults and thrusting characteristic of the situation in other collisional belts. With this event were associated the tensional basalt dike swarms, oblique to the main shear and transcurrent mylonitic zones. Ultramafic rocks accompanied the collision in a few places in Tandilia, probably as a result of "mantle pinching."

Structural patterns in the crystalline rocks of Uruguay and Argentina are similar. A main metamorphic event (F2M2 on Fig. 8) developed around $1850 \mathrm{Ma}$, deforming an older (2100 $\mathrm{Ma}$ ) metamorphic complex (FlM1) that originated as part of a pre-collision continent.

It is also notable that both cratonic areas contain swarms of sub-alkaline to tholeiitic diabase dikes that indicate the first stabilization event over the whole craton (1700 to 1600 $\mathrm{Ma}$. This took place immediately after the emplacement of the last post-tectonic (F2M2) leucogranites when the basement rocks still were in a plastic state, as indicated by the local deformation of the basic dikes.

This whole igneous-metamorphic belt could be part of a major unit that extended into southwest Africa, including units like the Vioolsdrif Suite (2000-1730 $\mathrm{Ma}$ ) and part of the Namaqualand-Natal belt (1700-1000 Ma) of Hartnady and others (1985). The northern part of the Uruguay cratonic region exhibits some lithological and structural features that could be interpreted as evidence of an Archean nucleus, though the oldest age determination here is $2200 \mathrm{Ma}$ ( $\mathrm{Rb}-\mathrm{Sr}$ ).

The Brazilian orogenic cycle $(900-500 \mathrm{Ma})$ is represented in Uruguay by a well-developed igneous-metamorphic belt assigned to a Wilson cycle by Porada (1979), with the granitic rocks of its central belt interpreted as a by-product of collisional tectonics (Fragoso et al., 1982). During these events in Argentina, the only equivalent metamorphic rocks known are those of the Punta Mogotes Formation.

It is important to realize the continuity of the syn- to posttectonic Brazilian sedimentary deposits that partly cover crystalline basement areas to the west of an important SSW-NNE alignment, which separates the Transamazonian from the Brazilian belts.

A correlation between $R$ io de la Plata craton and the southwestern corner of Africa is also possible by comparing the Brazilian cycle with the Pan-African (Porada, 1979; Fragoso et al., 1982; Ramos, 1988) and the stratigraphy of the pretectonic marine sediments of the La Tinta Group and the Piedras de Afilar Formation with the lower Nama Group. The Brazilian Cycle can be correlated with the Punta Mogotes Formation because they have the same age, they both have low metamorphic grades, and they are both east of a fault that bounds the Brazilian belt on the west.

Marine deposits could have resulted from the continental reassembling, at the end of the late Precambrian, during the Wilson cycle responsible for the metamorphism of the Punta Mogotes Formation. The Barriga Negra Formation could be considered a final molassic deposit with a Late Cambrian age. The late Precambrian-early Paleozoic polar wander path (Kröner et al., 1980; Valencio et al., 1980; Vilas and Valencio, 1978; Sinito, 1984) fits with the above-mentioned reconstruction.

Thus in the Rio de la Plata cratonic region two main orogenic cycles can be recognized: the Transamazonian (2.2-1.7 Ga) and the Brazilian (900-500 Ma). During the late Precambrian, a platform sedimentary cover developed, followed finally in the early Paleozoic by the deposition of a sequence of quartz-rich sediments with a rich ichnofauna. 


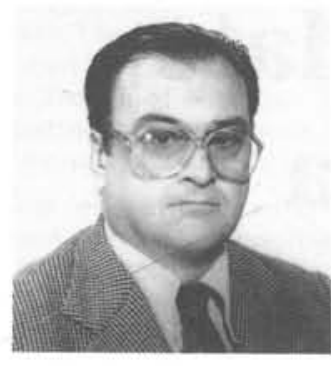

Dr. L.H. Dalla Salda is Professor in Structural Geology at the University of La Plata (Calle $1 \mathrm{~N}^{\circ}$. 644, 1900 La Plata, Argentina), Principal Researcher of the $\mathrm{Na}^{-}$ tional Research Council, and President of the Argentine Committee for the Lithosphere Program (ICL). $\mathrm{He}$ works on the structure and petrology of the southwest Gondwanaland crystalline basement.

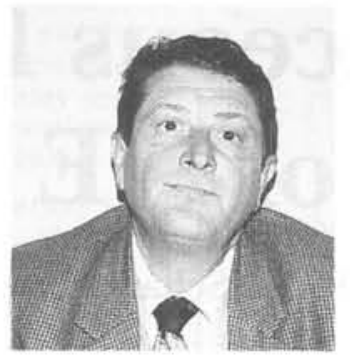

Dr. J. Bossi, is Professor of Geology at the Republica University (Av. Garzon 780, Montevideo, Uruguay). As a student he worked on the mineralogy of Precambrian iron ores, and in 1972 he earned a doctorate in metallogeny in France. Since 1965 he has studied pre-Devonian orogenic cycles and the metallogeny of Uruguay.

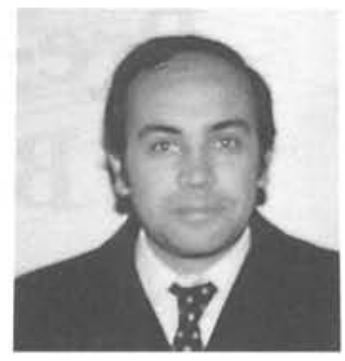

Dr. C.A. Cingolani is Professor of Geology at the University of La Plata (C.I.G., Calle $1 \mathrm{~N}^{\circ}$. 644, 1900 La Plata, Argentina). He is currently studying the stratigraphy, $\mathrm{Rb}-\mathrm{Sr}$ geochronology and evolution of late Precambrian to early Paleozoic rocks of Argentina, and is Coordinator of the National Geotransect Program and Secretary of the National IGCP Committee.
References

Bonhomme, M.G. and Cingolani, C.A., 1980. Mineralogin y geocronologia Rb-Sr y K-Ar de fracciones finas de in "Formacion La Tinta," Provincia de Buenos Aires. Revista de Asociacion Geologica Argentina, v. 35, no. 4, p. 519-538.

Borrello, A.V., 1966. Trazas, restos tubiformes y euerpos fosiles problematicos de la Formacion La Tinta, Sierras Septentrionales de la Provincia de Buenos Aires. Paleontografia Bonnerense, V. Comision Investaciones Cientificas Provincia Buenos Aires, $\mathrm{p}, 1-42$

Bossi, J., 1966. Geologia del Uruguay. Depto. Public. Univ., p. 1-412, Montevideo, Uruguay.

Bossi, J., 1983. Breve resena sobre el conocimiento zeologico del escudo predevoniann Uruguay (Sudamerica). Zentralblatt für Geologie und Paln̈ontologie, v. 1, no. 3-4, D. 417-429,

Bossi, J. and Navarro, R., 1982, Los "granitos negros" (microgabros) del Eocambriano del Uruguay. $v$ Congreso Latinoamericano de Geologia, v. 2, p. 23-35, Buenos Aires.

Bossi, J., Ferrando, L.A., Fernandez, A.N., Elizalde, G., Morales, H., Fond, I., Ledesma, J.J., Carballo, E., Medina, E, and Montana, J.R., 1975. Carta geologiea del Uruguay a escal $1: 1,000,000$.

Cingolani, C.A. and Bonhomme, M.G., 1982. Geochronology of La Tinta Upper Proterozoic sedimentary rocks, Angentina. Precambrian Research, v. 18, no, 1-2, p. 119-132.

Coronel, N., Oyhantçabal, P. and Spoturno, J., 1982. Consideraciones estructurales de th Formacion Piedras de Afilar en su area tipo, Canelones, Uruguay. Actas v. Congreso Latino

Dalla Salda, L.H., 1981a. El basamento de la Isla Martin Gareia, R io de la Plata, Revista de in Asociacion Geologica Argentina, v. 36, no. 1, p. 29-43.

Dalla Salda, L.H., 1981b. The Precambrian geology of EI Cristo, southern Tandilia region, Argentina. Geologische Rundschau, v. 70, no. 3, p. $1030-1042$,

Dalla Salda, L.H., 1981c. Tandilia, un ejemplo de tectonica de transeur

Revista de la Asociacion Geologica Argentina, v. 36, no, 2, 0. 204-207.

Dnilla Salda, L.H and Franzese, Ja in press. The 1800 m.y. Tandilin, Argentina. Basement Tectonics, 7 th International Conference, Kingston, Canada.

Dalla Salda, L.H. and Iñiguez, A.M., 1979. "La Tinta," Preeambrico y Paleozoleo de Buenos Aires. Vul Congreso Geologieo Argentino, v. I, p. 539-550, Buenos Aires

Dalla Salda, L.H., Guichon, M. and Rapelo, C.W., 1972. Hallazgo de una brecha de talud en el
techo de las calizas de Barker, Provineia de Buenos Aires, Republica Argentina, Revista do techo de las calizas de Barker, Provincia de Buenos Aires, Republica Argentina. Revista de
Asociacion Angentina Mineralogica, Petrologiea y Sedimentologica (AMPS), v. III, p. 133-134.

Fernandez, A. and Preciozzi, E., 1974. La Formacion Arroyo Grande y los granitoides asocindos Annis do XX VIII Congresso Brasileiro-de Geologia, p. 213-226, Porto Alegre, Brasil.

Ferrando, L. and Fernandez, A., 1971. Esquema teetonico estratigrafico del Predevoniano en Uruguay. Anais do XXV Congresso Brasiteiro de Geologin, p. 199-210, Sao Paulo, Brasil.

Fragoso Cesar, A.R.S., Wernick, E. und Soliani Jr., E., 1982, Evolucao geotectonica do einturao Dom Feliciano. Uma contribueao atraves da aplicaeao do modelo de tectonica de placas, Anuis

Fragoso Cesar, A.R.S., Machado, R. and Gornez Rifas, C., in press Observacoes sobre einturao Dom Feliciano no Escudo Uruguaio e corretacoes com o Escudo do Rio Grande do Sul. Anais do ill Symposio Geologico Sulbrasileiro, Curitiba, Brasit. Gonzalez Bonorino, F., Zandini, R., Figueroa, M. and Limousin, T., 1956. Estudio geologico de
las Sierras de Olavarria y Azul (Provincia de Ruenos Aires). LEMIr, MOP, Serie II, v. 63, p. 5-22, La Plata.

Halpern, M. and Linares, E., 1970. Edad Rubidio-Estroncio de las rocas graniticas del bassmento eristalino del area de Olavarrin, Provineia de Buenos Aires, Republica Argentina. Revista de in Asociacion Geologien Angentina, v. 25, no. 3. p. 303-306.

Halpern, M., Umpierre, M. and Linares, E., 1970. Rndiometric ages of erystalline rocks from southern. South America as related to Gondwann and Andenn geologic provinces. Actus
Conferencia Problematicas Tierra Solida, v. 2, p. 345- 355, Buenos Aires.

Hart, S.R., 1966. Radiometric ages in Uruguay and Argentina and their implications concerning continental drift. Abstract, Geologienl Society of America Special Paper no, 101, p, 86, Annual Mecting. San Franciseo, U.S.A.

Hart, S.R., Krogh, T.E., Davis, G.L., Aldrich, L.T. and Munizaga, F., 1967. A geochronologrieal approach to the continental drift hypothesis. Carnegie Institution, Yearbook 65, Washington,

Hartnady, C., Joubert, P. and Stowe, C., 1985. Proterozoic erustal evolution in southwestern Africa. Episodes, v. 8, no, 4, p. 236-244.
Iñizuez, A.M., del Valle, A., Poiré, D., Spalletti, L, and Zalba, P., 1987, Cueneas precambricn y paleozoica inferior de Tandilia. $X$ Congreso Geologico Argentino, v. 5, p. 19-20, Tueuman.

Iniguez, A.M. and Zalba, P., 1974. Nuevo nivel de areilitas en la zona de Cerro Negro, Partido de Olavarria, Provincia de Buenos Aires, LEMrT, v, 2, no, 264, P. 25-100.

Kröner, A., MeWilliams, M.O., Germs, G.J.8., Reid, A.B. and Schalk, K.E.L., 1980. Paleornagnetism of late Precambrian to early Paleozole mixtite-bearing formations in Namibia (South West Africa): The Nama Group and Blau- beker Formation. American Journal of Seience,

Marehese, H.G. and Di Paola, E., 1975. Reinterpretacion estratigrafica de la Perforacion de Punta Mogotes 1, Provincia de Buenos Aires, Revista de ta Asociacion Geologiea Angentino, V. 30 , no. 1 , p. 4 4. 52 .

Pearce, J.H., Harris, N.B, and Tindle, A.G., 1984. Trace element diserimination diagrams for the teetonic interpretation of granitic rocks. Journal of Petrolory, v. 25, no, 4, p. 956-983.

Pitcher, W.S., 1982. Granite type and tectonic environment. In: Hsij, K.J. (ed.), Mountain building processes, Academic Press, London, p. 19-40.

Porada, H., 1979. The Damara-Ribeira orogen of the Pan Africa-Brasiliano cycle in Namibin (Southwest Africa) and Brazil as interpreted in terms of continental collision. Tectonophysic

Pothe de Baldis, E.D., Baldis, B.A. and Cuomo, J., 1982. Los fosiles precambricos de in Formacion Sierras Bayas (Olavarria) y su importancia intercontinental. Revista de la Asociacio

Preciozzi, F., Spoturno, J., Heinzen, W. and Rossi, P., 1985. Memoria explieativa do th Cenrta Geologica del Uruguny $n$ escala $1: 500,000$, Dir. Nac. Min. Geologtia, p. 1-90, Montevideo. Uruguay.

Ramos, V.A., 1988. Late Proterozoic-early Paleozoic of southern South America: A collisional history. Episodes, v. 11, no. 3, p. 168-174.

Rapeln, C.W., Dalla Salda, L.H. and Cingolani, C.A., 1974. Un intrusivo basico ordovicico en th Formacion La Tinta (Sierra de los Barrientos) Provincia de Buenos Aires, Revista de Asociacion Geologien Argentinn, v. 29, no, 3, p. 319-331.

Sinito, A.M., 1984. Paleomagnetismo de roeas sedimentarias de ta Provincia de Buenos Aires, Asignadas ai Precambrico tardio y Paleozoico temprano. Revista de la Asocincion Geologiea
Angentina, v. 39, no. 1-2, p. 144-152.

Soltani Jr., E., 1986. Os dados geoc zologicos do Escudo Suiriograndense e suns implicacoes de ordem geotectonica. Tesis doutoramento, Universidade Sao Paulo, Brazil.

Spalletti, L.A. and Del Valle, A., 1984. Las diamictitas del sector oriental de Tandilias caracteres sedimentologicos y origen. Revista de ta Asociacion Geologica Angentina, v. 39,

Teruggi, M., Maurino, V., Limousin, T. and Schauer, O., 1958, Geologia de las Sierras de Tandil. Revista de in Asoeincion Geologica Angentina, v. 13, no. 3, p. 185-204. Terugki, M., Maurino, V. and Limousin, T., 1962. Geologia de la poreion oriental de las Sierras
del Tandil. Anales Primera Jornada Geologica Angentina, v. 2, p. 359-373.

Terugki, M., Kilmurray, J. and Dalla Salde, L.H., 1973. Los dominios tectonicos de la region de Tandil. Anales Sociedad Cientifica Argentina, v. 195, no. 1-2, p. $81-94$.

Teruggi, M., Kilmurray, J., Rapela, C. and Dalla Salda, L.H., 1974. Diques hasicos en las Sierras de Tandil. Revista de in Asocincion Geologica Arzentina, v, 29, no, 1, p, $41-60$.

Umpierre, M. and lialpern, M., 1971. Edades estroncio- rubidio en rocas eristalinas del sur de $1 \mathrm{k}$ Republica Oriental del Uruguav, Revista de la Asociacion Geologica Arsentina, v. 26, no. 2, p. $133-151$.

Velencio, D., Vilns, J.F. and Sinito, A., 1980. Paleomegnetismo y edades radimétricas de algunns formaciones neo-preeambriens y eopaleozoicas de la Angentina. Revista de ta Asociacion Geologiea Angentina, v. 35, no. 3, p. $421-433$ Varela, R., Dalla Saldn, L.H. and Cingolani, C.A., in press Lis cdar Rb-Sr del Giranito de Vela.
Tandil. Primeras dornades Geologicas Bonaerenses, Tandil (1945).

Varels, R., Cingolani, C.A. and Dalla Salda, L.H., 1988, Geocronologin Rb-St en granitoides del bassamento de Tandil, Prov. Buenos Aires, Argentinn, Segundas Jornadas Geologicas Bonaerense: p. 291-305, Bahia Btanea.

Vilas, J.F.A. and Valeneio, D.A., 1979. Paleomagnetism of South American roeks and the Z.wart, H.J., 1967. The tuality of orogente belts, Geologie en Migntouiv, v. 450, no. 8 , p. $283-309$. 